\section{Nauplius}

The Journal of The

Brazilian Crustacean Society

e-ISSN 2358-2936

www.scielo.br/nau www.crustacea.org.br
This article is part of the special series offered by the Brazilian Crustacean Society

in honor to Ludwig Buckup

his dedication and contributions to the development of Carcinology

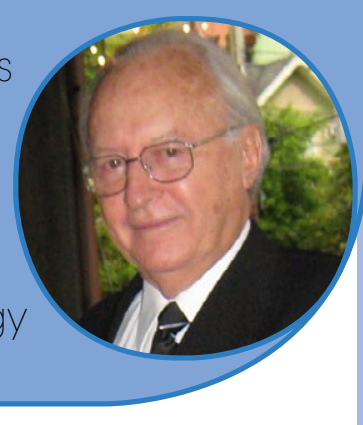

Original Article

\title{
Biometrical and morphological analyses of Macrobrachium olfersii (Wiegmann, 1836) (Crustacea, Decapoda, Palaemonidae) embryos exposed to UVA and UVB radiation
}

Yara Maria Rauh Müller ${ }^{1}$ iD orcid.org/0000-0002-4407-5018

Thaline de Quadros ${ }^{1}$ (iD orcid.org/0000-0002-6213-4077

Heloísa Schramm ${ }^{1}$ (iD orcid.org/0000-0002-9052-1808

Valquiria Machado Cardoso Weiss ${ }^{1}$ iD orcid.org/0000-0002-7489-6597

Eliane Cristina Zeni ${ }^{1}$ iD orcid.org/0000-0003-1031-0566

Evelise Maria Nazari ${ }^{1}$ (D) orcid.org/0000-0002-3635-0526

Dib Ammar² iD orcid.org/0000-0002-4192-6809

1 Departamento de Biologia Celular, Embriologia e Genética, Universidade Federal de Santa Catarina. Florianópolis, Santa Catarina, Brazil.

2 Centro Universitário Católica de Santa Catarina. Joinville, Santa Catarina, Brazil.

ZOOBANK: http://zoobank.org/urn:lsid:zoobank.org:pub:0ADBD37A-1D39-4296-

B4A5-B2C77F39E35C

\section{Abstract}

Macrobrachium olfersii (Wiegmann, 1836) is a prawn that lives in shallow and transparent freshwater in Southern Brazil. Aquatic organisms that inhabit

CORRESPONDING AUTHOR Yara Maria Rauh Müller yara.rauh@ufsc.br

SUBMITTED 4 October 2017 ACCEPTED 29 March 2018 PUBLISHED 21 June 2018

\section{Guest Editors}

Alessandra Angélica de Pádua Bueno and Sandro Santos

DOI 10.1590/2358-2936e2018013

\section{(cc) BY}

All content of the journal, except where identified, is licensed under a Creative Commons attribution-type BY.

Nauplius, 26: e2018013 these systems can be exposed to incident UV radiation. Many studies have demonstrated the effects of ultraviolet (UV) radiation on the development, survival rate, morphological abnormalities, and impairments in swimming behavior in crustaceans. However, fewer studies have elucidated how the embryos of crustaceans respond to the exposure of UV radiation. Thus, the aim of this study was to evaluate whether UVA and UVB affect biometrical and morphological parameters of eggs and embryos of M. olfersii. Embryos were divided into two groups: Group I, composed of embryonic day 7 (E7) to E10 and Group II, composed of E1 1 to E14. Both groups were irradiated with $60 \mathrm{~min}$ UVA and $30 \mathrm{~min}$ UVB. Non-irradiated embryos at the same 
stages were used as controls. UVA and UVB radiation induces variations in morphometric parameters, such as egg volume, egg water content, and eye index. UVB radiation also induced an increase of embryonic cell death. We conclude that the embryonic cells of M. olfersii respond differentially to UVA and UVB radiation in accordance with the evaluated parameters.

\section{KeY WORDS}

Prawn, embryonic development, egg volume, cell proliferation and death.

\section{INTRODUCTION}

The freshwater prawn Macrobrachium olfersii (Wiegmann, 1836) is widely distributed in tropical and subtropical regions, ranging from the southwestern United States to the south of Brazil (Holthuis and Provenzano, 1970). On the Island of Santa Catarina (Brazil), this species was collected in rivers and streams, particularly in the Ratones River and Peri Lagoon (Müller et al., 1999; Ammar et al., 2001).

Males and females of $M$. olfersii present similar body size until sexual maturity, similar to other palemonids (Bond-Buckup and Buckup, 1989). From sexual maturity, males invest energy in somatic growth, becoming the bigger individuals of the population, while females invest energy in yolky egg production and parental care, such as egg incubation in a brood pouch (Adiyodi and Subramonian, 1983). Decapods with yolky eggs exhibit different incubation times, ranging from 10 days for Palaemon argentinus (Nobili, 1901) (Nazari et al., 2000), 20 days for Macrobrachium rosenbergii (de Man, 1879) (Habashy et al., 2012), and 180 days for Homarus americanus H. Milne Edwards, 1837 (Helluy and Beltz, 1991). Macrobrachium olfersii ovigerous females carry out approximately 2,000 eggs per spawning in an external brood pouch for 14 days $\left(24 \pm 1^{\circ} \mathrm{C}\right)$ (Simões-Costa et al., 2005).

Different abiotic factors can affect the size and number of eggs and, therefore, may compromise reproduction of crustacean species (Charniaux-Cotton et al., 1992). The breeding season of M. olfersii occurs in late spring and summer in Southeast and South Brazil (Ammar et al., 2001; Mossolin and Bueno, 2002; Pescinelli et al., 2016), where high incidence of UV radiation is registered. The reduction of the ozone layer is related to the increase in the incidence of UVB radiation on the Earth's surface and depending on the dose received, this radiation can promote adverse biological effects on organisms (Hollmann et al., 2015;
Almeda et al., 2016; Bonaventura and Matranga, 2017). The UVB radiation has been reported to be an environmental stressor for $M$. olfersii embryos. In general, DNA is the cellular chromophore for UVB radiation, because its maximum absorbance coincides with the UVB wavelength (Hadshiew et al., 2000; Petit-Frère et al., 2000). Moreover, UVB radiation also interferes with the cell cycle, mitochondrial dynamics, cell viability, and induces DNA damage (Nazari et al., 2010, 2013; Zeni et al., 2015; Quadros et al., 2016).

Taking into account that (i) UV radiation is able to penetrate into aquatic environments, depending on the depth of the water column and the amount of suspended organic matter (Häder et al., 2007); (ii) M. olfersii inhabit shallow and clear waters (Ammar et al., 2001), and (iii) the ovigerous females carry embryos in an external brood pouch, we suggest that the eggs of this species are subject to the direct incidence of environmental UV radiation. Thus, UV radiation can compromise the viability of the embryos and cause greater consequences to the population. The aim of this study was to evaluate whether UVA and UVB radiation interfere with biometrical and morphological parameters of eggs and embryos of M. olfersii.

\section{Material And Methods}

\section{Animals}

We collected females $(25.40-58.20 \mathrm{~mm}$ and 0.18 $4.30 \mathrm{~g}$ ) and males (42.70-93.00 $\mathrm{mm}$ and 2.25-16.57 g) of M. olfersii during the spring and summer seasons from the Peri Lagoon/Santa Catarina Island ( $27^{\circ} 45^{\prime} \mathrm{S}$ $\left.48^{\circ} 32^{\prime} \mathrm{W}\right)$. The prawns were maintained in aquaria with dechlorinated, aerated tap water at $24^{\circ} \mathrm{C}\left( \pm 1^{\circ}\right)$ and a $12 \mathrm{~h}$ light: $12 \mathrm{~h}$ dark regime. The light cycle was set with a fluorescent lamp (Philips TLT 40 W/75 RS) irradiating visible light at $96 \mathrm{~mW} . \mathrm{cm}^{-2}$. The prawns were fed once a day with commercial pellet food Alcon Bottom Fish. To obtain embryos under laboratory conditions, males 
and non-ovigerous females (1:3) were placed in small aquaria, where courtship and fertilization occurred. The collection procedures adopted in this study were approved by the Instituto Brasileiro do Meio Ambiente e dos Recursos Naturais Renováveis (Certificate number 15294-1/IBAMA/2008).

\section{Irradiation procedures}

To evaluate the effects of UVA and UVB radiation, ovigerous females were divided into two experimental groups. In group I, ovigerous females with eggs from embryonic day 3 (E3) to E6 were exposed once to a UVA lamp (Vilber Lourmat, 6W - $365 \mathrm{~nm}$ ) for $60 \mathrm{~min}$ or once to a UVB lamp (Vilber Lourmat, $6 \mathrm{~W}-312 \mathrm{~nm}$ ) for $30 \mathrm{~min}$. Following this, ovigerous females were kept in the dark for 4 days. Thus, in group I, embryos were analyzed from E7 to E10, which corresponds to initial eye pigmentation to the formation of oval shaped eyes. In group II, ovigerous females with eggs from E7 to E10 were exposed to a UVA lamp (Vilber Lourmat) for 60 min or UVB lamp (Vilber Lourmat) for $30 \mathrm{~min}$. Following this, ovigerous females were kept in the dark for 4 days. Group II embryos were analyzed from E11 to E14, which corresponds to initial rounded eyes until hatching. Non-irradiated embryos from E7 to E14 were used as controls. The irradiance of UVA was $0.94 \mathrm{~mW} . \mathrm{cm}^{-2}$ with contamination of $0.003 \mathrm{~mW} . \mathrm{cm}^{-2}$ UVB and the irradiance of UVB was $310 \mathrm{~mW} \cdot \mathrm{cm}^{-2}$ with contamination of $0.055 \mathrm{~mW} \cdot \mathrm{cm}^{-2}$ UVA. Measurements of UVA and UVB irradiances were made using a radiometer (International Light, model IL 1400A) and the doses were calculated according to Diffey (2002).

\section{Egg volume and water content}

Samples of irradiated eggs from E7-E10 (group I) and E11-E14 (group II) were measured using a morphometric eyepiece (Olympus; 40× magnification) to obtain the long and short axis of the eggs $(\mathrm{n}=$ 20 eggs per group/ 5 ovigerous females/irradiation procedure). The egg volume was calculated according to the formula: $\left(\pi \mathrm{lh}^{2} / 6\right)$, where $\mathrm{l}$ is the long axis and $\mathrm{h}$ is the short axis, according to Odinetz-Collart and Rabelo (1996). To determine the water content, samples of approximately $100 \mathrm{mg}$ of wet eggs $(\mathrm{n}=2$ ovigerous females for each embryonic day/irradiation procedure) were dehydrated at $50^{\circ} \mathrm{C}$ for $48 \mathrm{~h}$. The dried eggs were then weighed, and the water content was calculated as the difference between the wet and dry weight of the eggs, and expressed as a percentage.

\section{Eye index}

The eye index was calculated according to Perkins (1972) by the average of the length and width of the pigmented area of the eyes. Eye measurements were performed using a morphometric eyepiece (Olympus; 400 $\times$ magnification) ( $\mathrm{n}=10$ embryos for each embryonic day/5 ovigerous females/irradiation procedure).

\section{Developmental rhythms}

Developmental rhythms were characterized by daily analysis (Olympus; 70x magnification) of UVA and UVB-irradiated embryos from E7 to E14 ( $\mathrm{n}=$ approximately 100 embryos per group/5 ovigerous females/irradiation procedure) and compared with non-irradiated embryos to verify the external morphological features predictable for each embryonic day, as described by Simões-Costa et al. (2005). Morphological features considered were (i) shape of the embryos and egg size, (ii) eye shape and pigmentation, (iii) growth of caudal papilla, naupliar, and post-naupliar appendages, and (iv) presence of chromatophores.

\section{Immunohistochemical analysis}

To evaluate whether UVA and UVB radiation interferes with cell proliferation and cell death, embryos were fixed in $10 \%$ formaldehyde and embedded in paraffin and serial sections $(6 \mu \mathrm{m})$ were obtained using a rotary microtome. Sections were dewaxed, washed in 0.1 M phosphate-buffered saline (PBS; $\mathrm{pH} 7.4$ ), and maintained for $10 \mathrm{~min}$ in 3\% hydrogen peroxide in methanol to inactivate endogenous peroxidases. The sections were washed in $0.1 \mathrm{M}$ PBS $+0.3 \%$ Triton X-100 and maintained for $45 \mathrm{~min}$ in $5 \%$ fetal bovine serum to block non-specific binding of immunoglobulins. The sections were incubated overnight at $4^{\circ} \mathrm{C}$ with the mitosis marker, rabbit anti-phospho-histone $\mathrm{H} 3$ (PHH3) IgG antibody (1:200; Upstate/Millipore) and with rabbit anti-caspase-3 IgG antibody (1:100, Santa Cruz Biotechnology) to recognize apoptotic cells. Afterwards, the sections were washed with 0.1 MPBS $+0.1 \%$ Triton X-100 and incubated with peroxidaseconjugated secondary anti-rabbit IgG antibody (1:200; 
Sigma) for $3 \mathrm{~h}$ at room temperature. Antibody binding sites were revealed with 3,3'-diaminobenzidine (DAB; Sigma). Negative controls for the immunohistochemical reactions were treated in the same way as above, except that the primary antibodies were replaced with $0.1 \mathrm{M}$ PBS buffer ( $\mathrm{pH}$ 7.4). The numerical density per area (NA) of immunolabeled cells was determined in a $14.544 \mu \mathrm{m}^{2}$ frame (Mandarim-de-Lacerda, 2003). Five random fields of embryos were counted for each section ( $n=45$ embryos per group $/ 5$ ovigerous females/irradiation procedure).

\section{Statistical analysis}

Quantitative data were analyzed using Statistica 13.0 for Windows. The differences among the groups after UVA and UVB radiation were evaluated by oneway analysis of variance, followed by Tukey's post hoc test. $\mathrm{p}<0.05$ was considered statistically significant.

\section{Results}

Effects of UVA and UVB radiation on biometrical parameters

During embryonic development, non-irradiated eggs of $M$. olfersii showed a significant increase in volume between groups I $\left(0.042 \pm 0.0005 \mathrm{~mm}^{3}\right)$ and II $\left(0.060 \pm 0.001 \mathrm{~mm}^{3} ; \mathrm{p}<0.01\right)$ (Tab. 1). However, for UVA and UVB-irradiated eggs, no significant difference was found between the volumes of groups I ( 0.053 \pm 0.001 and $0.051 \pm 0.001 \mathrm{~mm}^{3}$, respectively) and II $\left(0.05 \pm 0.002\right.$ and $0.06 \pm 0.0007 \mathrm{~mm}^{3}$, respectively) When egg volume was compared among the irradiation procedures in the same group, no significant difference was found in group I. For group II, only UVA-irradiated eggs showed a lower egg volume $\left(0.050 \pm 0.002 \mathrm{~mm}^{3}\right.$; $\mathrm{p}<0.0001)$ compared with non-irradiated and UVBirradiated eggs.

The water content of the eggs showed a significant increase between groups I $(67.8 \pm 0.8 \%)$ and II (76.9 $\pm 0.9 \% ; \mathrm{p}<0.0001)$ in the non-irradiated controls. The same was observed between groups I and II of UVA- $(68.3 \pm 1.0$ and $76.9 \pm 0.4 \% ; \mathrm{p}<0.0001)$ and UVB-irradiated eggs (70.9 \pm 0.3 and $77.2 \pm 0.3 \%$; $\mathrm{p}<0.0001)$. UVB irradiation induced a significant increase in water content only in group I (Fig. 1).
Table 1. Egg volume of Macrobrachium olfersii from groups I and II in each UVA and UVB irradiation procedure.

\begin{tabular}{lcc}
\hline Eggs Volume $\left(\mathrm{mm}^{3}\right)$ & Group I & Group II \\
\hline Non-irradiated & $0.042^{\mathrm{a}, \mathrm{A}}( \pm 0.0005)$ & $0.060^{\mathrm{b}, \mathrm{A}}( \pm 0.001)$ \\
UVA & $0.053^{\mathrm{a}, \mathrm{A}}( \pm 0.001)$ & $0.050^{\mathrm{a}, \mathrm{B}}( \pm 0.002)$ \\
UVB & $0.051^{\mathrm{a}, \mathrm{A}}( \pm 0.001)$ & $0.061^{\mathrm{a}, \mathrm{A}}( \pm 0.0007)$ \\
\hline
\end{tabular}

Data are presented as mean \pm SEM. Lowercase letter indicates significant difference of the egg volume in each irradiation procedures between groups I and II. Uppercase letter indicates significant difference of the egg volume between irradiation procedures in the same group.

\section{Effects of UVA and UVB on the eye index}

The eye index was obtained from E7, when the eye pigmentation was first recognized. During development, the eye index progressively grows. The eye index showed slightly variations from E7 to E14 in embryos exposed to UVA and UVB radiation and also non-irradiated embryos. Therefore, UVA and UVB radiation did not induce significant variations in the eye index in both groups in comparison to non-irradiated embryos (Fig. 2).

Effects of UVA and UVB on developmental rhythms

Accompaniment of the embryonic development rhythm of $M$. olfersii observed that $10 \%$ of UVA and UVB-irradiated embryos in group I did not show a developmental delay (Fig. 3). We also observed that $15 \%$ of UVA- and $10 \%$ of UVB-irradiated embryos showed a developmental delay of $12 \mathrm{~h}, 70 \%$ of UVAand $60 \%$ of UVB-irradiated embryos showed a developmental delay of $24 \mathrm{~h}$, and $5 \%$ of UVA- and $15 \%$ of UVB-irradiated embryos showed a developmental delay of $48 \mathrm{~h}$. The development delay in group II gradually decreased, evidenced by the absence of embryos with a developmental delay greater than $24 \mathrm{~h}$.

\section{Effects of UVA and UVB irradiation on cell proliferation} and cell death

Immunohistochemical reaction using antibodies against $\mathrm{PHH} 3$ and caspase- 3 was used to evaluate if $U V$ radiation affects cell proliferation and death, which are essential mechanisms of embryonic development. Labeling was observed in various embryonic structures, including the caudal papilla, appendages, and optic lobes.

The density per area (NA) of PHH3-positive cells, which indicated cell proliferation, showed that 


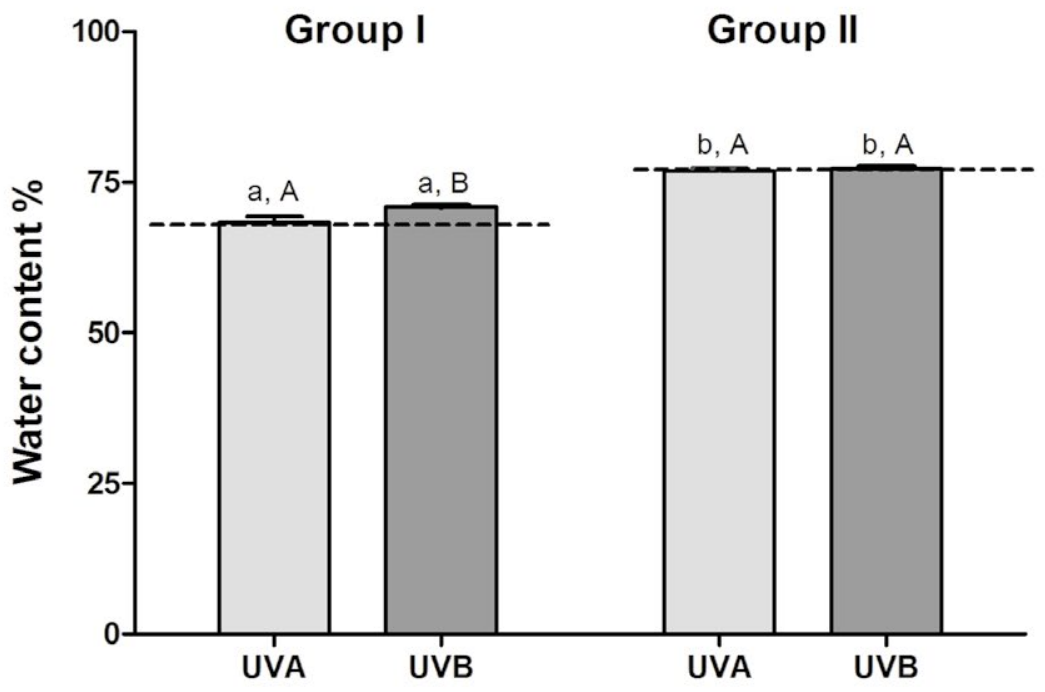

Figure 1. Percentages of water content of eggs of Macrobrachium olfersii from groups I and II following UVA and UVB exposure. Data are presented as the mean \pm standard error of the mean (SEM). Dashed lines correspond to the percentage of water content of non-irradiated eggs from groups I and II. Lowercase letter indicates significant difference in each irradiation procedure between groups I and II. Uppercase letter indicates significant differences of the water content among irradiation procedures in the same group.

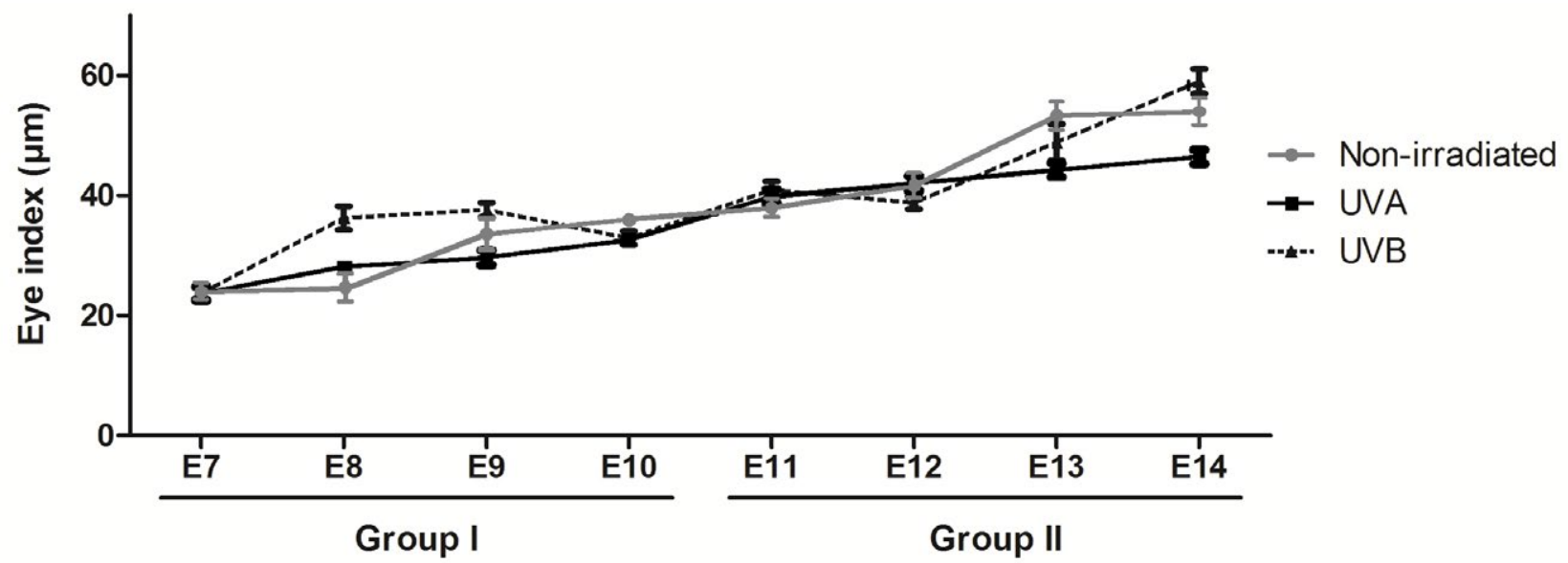

Figure 2. Eye index of embryos of Macrobrachium olfersii from groups I and II following UVA and UVB exposure. Data are presented as the mean \pm SEM. Gray, black, and dashed lines correspond to non-irradiated, UVA-irradiated, and UVB-irradiated embryos, respectively.

embryos exposed to UVA in both group I (95.42 \pm $\left.6.01 \mathrm{~mm}^{2}\right)$ and group II $\left(114.59 \pm 12.9 \mathrm{~mm}^{2}\right)$ did not differ compared with non-irradiated embryos $(94.01$ $\pm 5.2 \mathrm{~mm}^{2}$ ). Following UVB exposure, the density of PHH3-positive cells decreased in both group I $\left(91.67 \pm 10.0 \mathrm{~mm}^{2} ; \mathrm{p}<0.03\right)$ and II $\left(92.61 \pm 4.0 \mathrm{~mm}^{2}\right.$; $\mathrm{p}<0.04)$ respectively, compared with non-irradiated embryos (Fig. 4A-G).

The density per area (NA) of caspase-3-positive cells, which is indicative of cell death, showed a significant increase in the embryos of group I exposed to UVA $\left(143.5 \pm 9.7 \mathrm{~mm}^{2} ; \mathrm{p}<0.02\right)$ and UVB (140.32 $\left.\pm 8.0 \mathrm{~mm}^{2} ; \mathrm{p}<0.03\right)$, compared with non-irradiated embryos ( $\left.113.6 \pm 6.3 \mathrm{~mm}^{2}\right)$. In group II, only embryos exposed to UVB showed a significant increase (236.5 $\left.\mathrm{mm}^{2} \pm 12.3 ; \mathrm{p}<0.01\right)$ compared with non-irradiated embryos $\left(127.7 \pm 17.6 \mathrm{~mm}^{2}\right)$. No significant difference was found in embryos exposed to UVA $(171.89 \pm 23.6$ $\mathrm{mm}^{2}$ ) (Fig. 4H-N). 
UVA

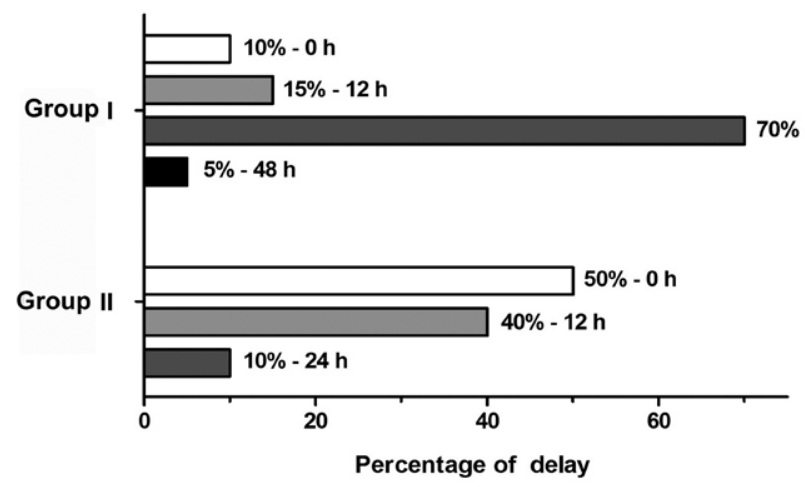

Group 1

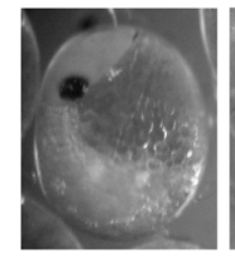

Non-irradiated

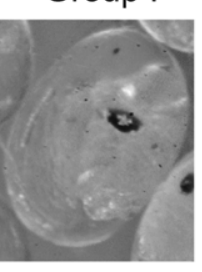

UVA

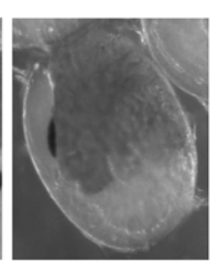

UVB
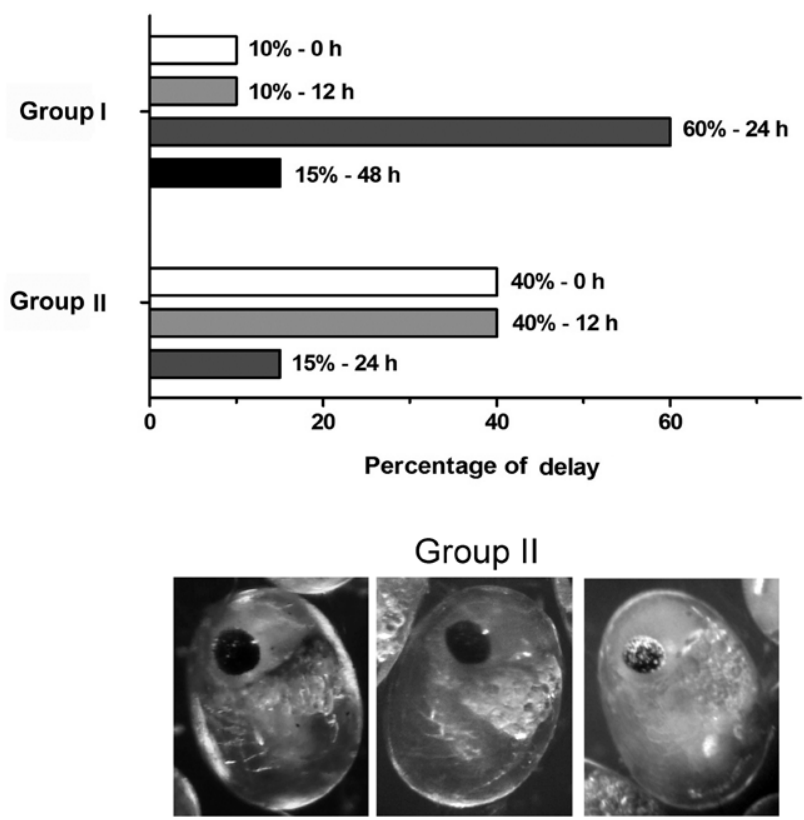

Non-irradiated

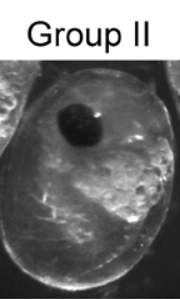

UVA

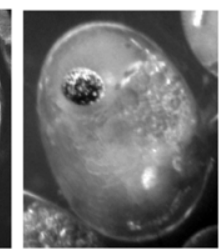

UVB

Figure 3. Developmental timelines of Macrobrachium olfersii embryos from groups I and II following UVA and UVB exposure. Data are presented as a percentage.

\section{DISCUSSION}

Aquatic animals are subject to UV radiation, which depends on water clarity as well as other factors. Several studies have demonstrated that different species have different sensitivities to UV exposure, and there are few studies reporting the effects on aquatic invertebrate embryos. Moreover, it is important to consider that embryos are more sensitive to environmental stressors than organisms at later life stages. Together, these considerations highlight the importance of studies that evaluate the responses of aquatic embryos to UV exposure.

It has been well established that the eye index is an important morphological landmark in the development of crustaceans (Helluy and Beltz, 1990) and in M. olfersii, the presence of the lateral eyes can be observed at approximately $50 \%$ of the embryonic development time (Müller et al., 2003). In this study, the irradiance and the exposure time of UVA and UVB radiation did not disturb the eye index. The same way, the eye index was not disturbed in a study performed by Nazari et al. (2010), which evaluated the effect of 310 $\mathrm{mW} . \mathrm{cm}^{-2}$ UVB in M. olfersii embryos. These authors also demonstrated that this index was not disturbed in embryos exposed to solar UVB radiation.
Under controlled temperature conditions, the development of $M$. olfersii occurs in 14 days (SimõesCosta et al., 2005). However, UVA and UVB irradiation results in a significant developmental delay. This delay may be related to the unbalance between proliferation and apoptosis observed in embryonic cells following UV irradiation. It is important to note that during embryonic development, cell division is fast (Ninov et al., 2009), which may compromise the detection of damage and promote the propagation of damage to descendent cells.

Apoptosis also serves to maintain the integrity of tissues of organisms when they are exposed to extrinsic stimuli that promote cell damage (Zhou and Steller, 2003). Caspase-3 is a protein involved in the cascade that triggers apoptosis, and is one of the last signals to be activated, promoting the cleavage of DNA and the formation of apoptotic bodies (Cohen, 1997). Cell proliferation and death are essential for morphogenesis and organogenesis events. The interference of external agents, such as UV radiation, may compromise the adequate development of embryos (Nazari et al., 2013). In the present work, it was verified that exposure to both UVA and UVB was able to induce alterations in 

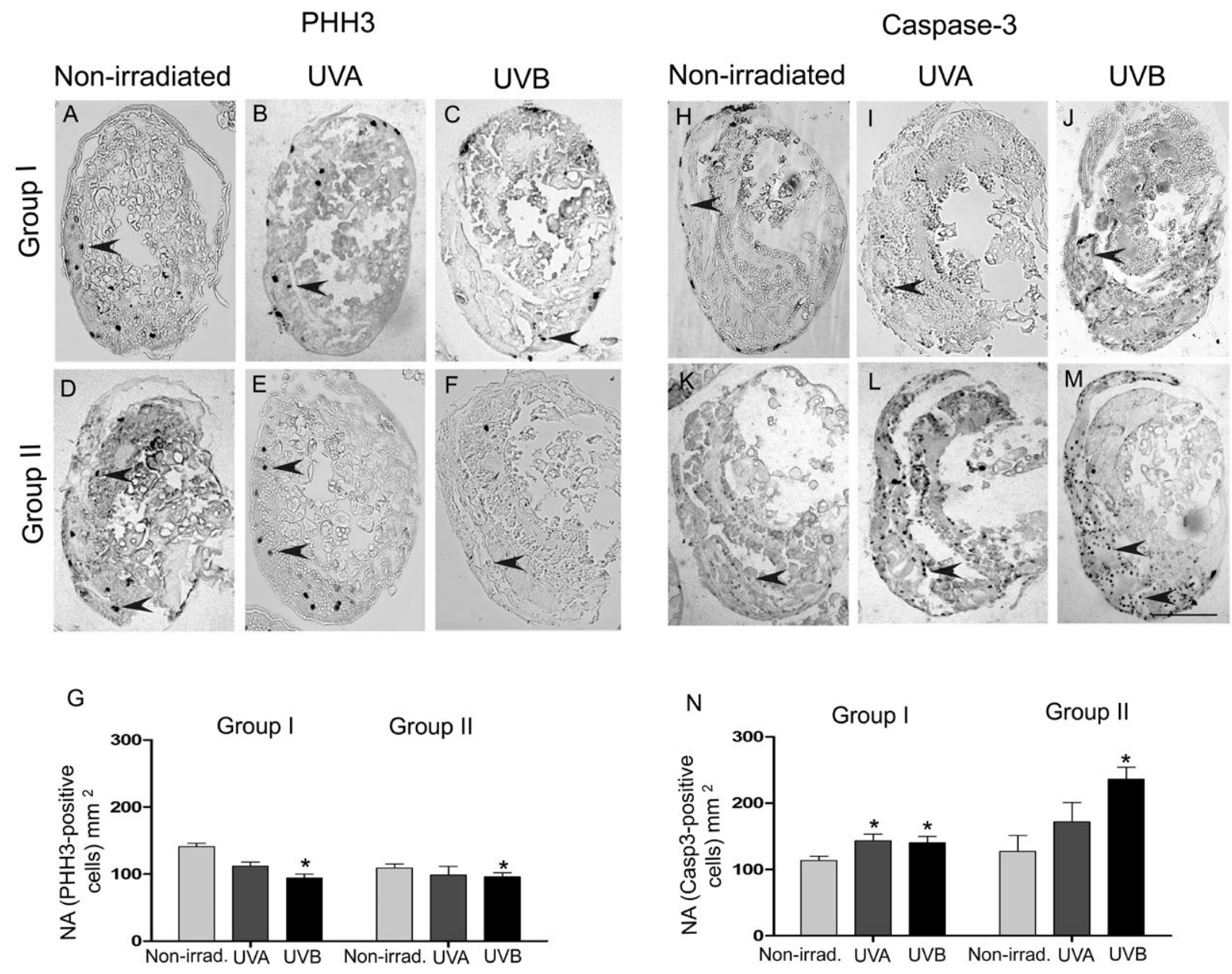

Figure 4. Cell proliferation and cell death labeled with anti-PHH3 (arrowhead) and anti-caspase-3 (arrowhead) antibodies in embryos exposed to UVA and UVB. Numerical density per area (NA) of proliferating cells of embryos from group I and II (A-G). NA of death cells from groups I and II (H-N). Data are presented as the mean \pm SEM.

the embryos of $M$. olfersii, promoting an unbalance between proliferation and apoptosis in embryonic cells.

Studies performed with other crustaceans, such as the crab Ucides cordatus (Linnaeus, 1763) (Vargas et al., 2010; Hollmann et al., 2016), have shown that the cells of these organisms also trigger apoptosis in response to UVB exposure. In embryos of M. olfersii, UVB radiation induced cell cycle arrest, DNA damage, and apoptosis (Zeni et al., 2015; Schramm et al., 2017). Apoptosis occurs normally during embryogenesis (Agnello and Roccheri, 2010), however, the increase in the number of apoptotic cells in the UV-exposed group indicates the action of radiation on this cell mechanism, and suggests it may interfere with the processes of morphogenesis and organogenesis.

In summary, we conclude that the embryonic cells of $M$. olfersii respond differentially to UVA and UVB radiation in accordance with the evaluated parameters. Considering the alterations observed, new studies focusing on the photobiological effects of UV radiation on aquatic organisms will be necessary, since UV radiation has been considered an environmental stressor and these organisms are essential for the maintenance of aquatic biodiversity.

\section{ACKNOWLEDGEMENTS}

This work was supported by CAPES (Coordenação de Aperfeiçoamento de Pessoal de Nível Superior, 425/2010) and CNPq (Conselho Nacional de Desenvolvimento Científico e Tecnológico, 475788/2011-7 and 456485/2014-7).

\section{References}

Adiyodi, R.G and Subramonian, T. 1983. Oogenesis, ovoposition and oosorption in Crustacea. p. 443-495. In: K.G. Adiyodi 
(ed), Reproductive biology of Crustacea, vol. I. Chichester, John Wiley \& Sons.

Agnello, M. and Roccheri, M.C. 2010. Apoptosis: focus on sea urchin development. Apoptosis, 15: 322-330.

Almeda, R.; Harvey, T.E.; Connelly, T.L.; Baca, S. and Buskey, E.J. 2016. Influence of UVB radiation on the lethal and sublethal toxicity of dispersed crude oil to planktonic copepod nauplii. Chemosphere, 152: 446-458.

Ammar, D.; Müller, Y.M.R. and Nazari, E.M. 2001. Biologia reprodutiva de Macrobrachium olfersii (Wiegman) (Crustacea, Decapoda, Palaemonidae) coletados na Ilha de Santa Catarina, Brasil. Revista brasileira de Zoologia, 18: 529-537.

Bonaventura, R. and Matranga, V. 2017. Overview of the molecular defense systems used by sea urchin embryos to cope with UV radiation. Marine Environmental Research, 128: 25-35.

Bond-Buckup, G. and Buckup, L. 1989. Os Palaemonidae de águas continentais do Brasil Meridional (Crustacea, Decapoda). Revista brasileira de Biologia, 49: 883-896.

Charniaux-Cotton, H.; Payen, G.G. and Ginsburger-Vogel, T. 1992. Arthropoda-Crustacea: sexual differentiation. p. 281324. In: K.G. Adiyodi and R.G. Adiyodi (eds), Reproductive Biology of Invertebrates. Vol. 5. New York, Wiley \& Sons.

Cohen, G.M. 1997. Caspases: the executioners of apoptosis. Biochemical Journal, 15: 1-16.

Diffey, B.L. 2002. What is light? Photodermatology, Photoimmunology and Photomedicine, 18: 68-74.

Habashy, M.M.; Sharshar, K.M. and Hassan, M.M. 2012. Morphological and histological studies on the embryonic development of the freshwater prawn, Macrobrachium rosenbergii (Crustacea, Decapoda). The Journal of Basic and Applied Zoology, 65: 157-165.

Häder, D.P.; Helbling, E.W.; Williamson, C.E. and Worrest, R.C. 2011. Effects of UV radiation on aquatic ecosystems and interactions with climate change. Photochemical and Photobiological Sciences, 10: 242-260.

Häder, D.P.; Kumar, H.D.; Smith, R.C. and Worrest, R.C. 2007. Effects of solar UV radiation on aquatic ecosystems and interaction with climate chance. Photodermatology, Photoimmunology and Photomedicine, 6: 267-285.

Hadshiew, I.M.; Eller, M.S. and Gilchrest, B.A. 2000. Skin aging and photoaging: the role of DNA damage and repair. American Journal of Contact Dermatitis, 11: 19-25.

Helluy, S.M. and Beltz, B.S. 1990. Stages in the embryonic development of the American lobster Homarus americanus with special emphasis on its nervous systems. p. 530-536. In: K. Wiese; W.D. Krenz; J. Tautz; H. Reichert and B. Mulloney (eds), Frontiers in Crustacean Neurobiology. Basel, Boston, Birkhaüser.

Helluy, S.M. and Beltz, B.S. 1991. Embryonic development of the American Lobster (Homarus americanus): Quantitative staging and characterization of and embryonic molt cycle. Biological Bulletin, 180: 355-371.
Hollmann, G.; Ferreira, G.J.; Geihs, M.A.; Vargas, M.A.; Nery, L.E.M.; Leitão, A.; Linden, R. and Allodi, S. 2015. Antioxidant activity stimulated by ultraviolet radiation in the nervous system of a crustacean. Aquatic Toxicology, 160: 151-162.

Hollmann, G.; Linden, R.; Giangrande, A. and Allodi, S. 2016. Increased p53 and decreased p 21 accompany apoptosis induced by ultraviolet radiation in the nervous system of a crustacean. Aquatic Toxicology, 173: 1-8.

Holthuis, L.B. and Provenzano, A.J. 1970. New distribution records for species of Macrobrachium with notes on the distribution of the genus in Florida (Decapoda, Palaemonidae). Crustaceana, 19: 211-213.

Mandarim-de-Lacerda, C.A. 2003. Stereological tools in biomedical research. Anais da Academia brasileira de Ciências, 75: 469-486.

Mossolin, E.C. and Bueno, S.L. 2002. Reproductive biology of Macrobrachium olfersii (Decapoda, Palaemonidae) in São Sebastião, Brazil. Journal of Crustacean Biology, 22: 367-376.

Müller, Y.M.R.; Nazari, E.M.; Ammar, D.; Cargnin Ferreira, E.; Beltrame, I.T. and Pacheco, C. 1999. Biology of Palaemonidae (Crustacea, Decapoda) from the Ratones Hidrografic Basin, Florianópolis, Santa Catarina, Brazil. Revista brasileira de Zoologia, 16: 629-636.

Nazari, E.M.; Ammar, D.; de Bem, A.F.; Latini, A.; Müller, Y.M.R. and Allodi, S. 2010. Effects of environmental and artificial UV-B radiation on freshwater prawn Macrobrachium olfersii embryos. Aquatic Toxicology, 98: 25-33.

Nazari, E.M.; Ammar, D.; Müller, Y.A.R. and Allodi, S. 2013. Impacts of ultraviolet-B radiation on aquatic embryos. $p$. 103-118. In: S. Allodi and E.M. Nazari (orgs), Exploring Themes on Aquatic Toxicology. Kerala, Research Signpost, 1.

Nazari, E.M.; Simões-Costa, M.S.; Müller, Y.M.R.; Ammar, D. and Dias, M. 2003. Comparisons of fecundity, egg size and egg mass volume on the freshwater prawns Macrobrachium potiuna and Macrobrachium olfersi (Decapoda, Palaemonidae). Journal of Crustacean Biology, 23: 862-868.

Ninov N.; Manjon, C. and Martin, E. 2009. Dynamic control of cell cycle and growth coupling by ecdysone, EGFR and PI3K signaling in Drosophila histoblasts. Plos Biology, 7: 892-903.

Odinetz-Collart, O. and Rabelo, H. 1996. Variation in egg size of the freshwater prawn Macrobrachium amazonicum (Decapoda, Palaemonidae). Journal of Crustacean Biology, 16: 684-688.

Perkins, H.C. 1972. Developmental rates at various temperatures of embryos of the northern lobster (Homarus americanus Milne-Edwards). Fishery Bulletin, 70: 95-99.

Pescinelli, R.A.; Carosia, M.F.; Pantaleão, J.A.F.; Simões, S.M. and Costa, R.C. 2016. Population biology and size at the onset of sexual maturity of the amphidromous prawn Macrobrachium olfersii (Decapoda, Palaemonidae) in an urban river in southeastern Brazil. Invertebrate Reproduction and Development, 60: 134-143.

Petit-Frère, C.; Capulas, E.; Lowe, J.E.; Koulu, L.; Marttila, R.J.; Jaspers, N.G.; Clingen, P.H.; Green, M.H. and Arlett, C.F. 
2000. Ultraviolet-B-induced apoptosis and cytokine release in xeroderma pigmentosum keratinocytes. Journal of Investigative Dermatology, 115: 687-693.

Quadros, T.; Schramm, H.S.; Zeni, E.C.; Simioni, C.; Allodi, S.; Müller, Y.M.R.; Ammar, D. and Nazari, E.M. 2016. Developmental effects of exposure to ultraviolet $\mathrm{B}$ radiation on the freshwater prawn Macrobrachium olfersii: Mitochondria as a target of environmental UVB radiation. Ecotoxicology and Environmental Safety, 132: 279-287.

Simões-Costa, M.S.; Pacheco, C.; Nazari, E.M.; Müller, Y.M.R. and Ammar, D. 2005. Estagiamento de embriões de Macrobrachium olfersii (Wiegman) (Crustacea, Palaemonidae) através de critérios morfológicos nos dias embrionários. Revista brasileira de Zoologia, 22: 501-508.
Vargas, M.A.; Geish, F.E.; Maciel, B P.; Cruz, D.M.V.B.; Filgueira, G.J.; Ferreira, L.E.M. and Allodi, S. 2010. Influence of the dark/light rhythm on the effects of UV radiation in the eyestalk of the crab Neohelice granulata. Comparative Biochemistry and Physiology-Part C: Toxicology \& Pharmacology, 151:343-350.

Zeni, E.C.; Ammar, D.; Leal, M.L.; Silva, H.S.; Allodi, S.; Müller, Y.M.R. and Nazari, E.M. 2015. Light-mediated DNA repair prevents UVB-induced cell cycle arrest in embryos of the crustacean Macrobrachium olfersii. Photochemistry and Photobiology, 91: 869-878.

Zhou, L. and Steller, H. 2003. Distinct pathways mediate UVinduced apoptosis in Drosophila embryos. Developmental Cell, 4: 599-605. 